\section{ANNUAL CONFERENCE}

The 1991 ASMS Conference on Mass Spectrometry will be at the Opryland Hotel in Nashville, Tennessee, May 19-24, 1991. Vice President for Arrangements, Robert P. Lattimer, reports that the hotel meeting facilities are among the best in the United States. Two large ballrooms on either side of a broad foyer will house all sessions, including the posters. There will be ample space to display up to 200 posters at one time.

Vice President for Programs, Henry M. Fales, will return to the traditional ASMS program of three concurrent oral sessions plus posters during both the morning and afternoon. The morning sessions will lead off with a plenary lecture. Posters will remain in place all day with authors present at designated periods throughout the day. Evenings will be available for workshops and corporate hospitality suites.

One highlight of the conference will be the "Wednesday Banquet." We will experience an antebellum evening at the Hermitage, the exquisite plantation of Andrew Jackson, the seventh President of the United States. As you approach the mansion through a tree-lined boulevard, you will be served a mint julep and have a leisurely opportunity to tour the home, gardens, and museum. The walkways, illuminated by lanterns, will lead you to the "cabin by the spring" for a dinner recreated from a menu often served at the Hermitage in the 1820s. The caterer will be Phila Hach, a Nashville personality renowned for her television cooking shows.

\section{SANIBEL CONFERENCE}

The Sanibel Conference will be January 29-February 1, 1991. The topic is Ion Activation and Dissociation and is organized by Richard Caprioli and Robert Boyd. The registration is limited to 125 persons in order to keep the agenda informal. Additional information may be obtained from the Society Office.

\section{SHORT COURSES}

ASMS will sponsor five short courses on May 18 and 19 , immediately preceding the annual conference in Nashville. A new course being offered this year only is Advanced Interpretation of Mass Spectra, taught by Fred McLafferty and Frank Turecek. The following is a complete list of the short courses:
Introduction to the Interpretation of Mass Spectra, organized by the Washington, DC, Mass Spectrometry Discussion Group

Advanced Interpretation of Mass Spectra, organized by Fred McLafferty and Frank Turecek

LC/MS, organized by Al Yergey and John Coutant

Fundamentals of Protein Analysis, organized by Barbara Larsen and Charles McEwen

GC/MS Methods in Drug Testing, organized by Rodger Foltz, Jack Henion, and John Cody

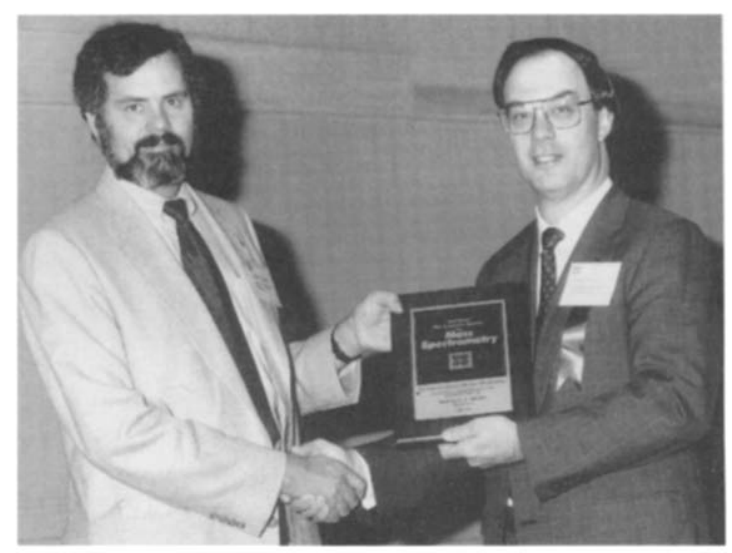

Robert C. Murphy (left) President of ASMS, and Ronald A. Hites, Past President

In July, Ronald A. Hites retired as President of ASMS. During his 2-year tenure, the Society undertook a number of new initiatives that will have lasting impact. The following are Ron's remarks to ASMS at the 1990 Annual Conference in Tucson.

\section{President's Report, 1989-1990 Ronald A. Hites}

The American Sociely for Mass Spectrometry is a healthy organization, both intellectually and financially. The intellectual quality of our Society is reflected by the high quality meetings that we sponsor and by the new Journal; more on this later. The fnancial health of the Society is, in part, measured by our year-end balance. As of the end of 1989, we had over $\$ 360,000$ on hand. More importantly, the rate of increase of this year-end balance has been about $15 \%$ per year for each of the last 3 years. The number of attendees at the annual conference has been growing 
about $8 \%$ per year. If we were a profit-making business, we would be a good investment. Clearly, from a business perspective, things look very good.

Much of the intellectual business of the Society is transacted at its annual meeting and at several smaller meetings. The 1989 annual meeting in Miami Beach was very successful by all measures. People were particularly impressed with the large poster session room, which allowed posters to be available for an entire day. We hope to be able to continue this format at future meetings. The Turson meeting was somewhat of an experiment for us. It was the first time that we met at two different hotels. This meeting was the biggest we have ever had, both in terms of the number of papers presented and the number of attendees. Bob Murphy, our Vice President for Programs for these two meetings, deserves our praise and gratitude. Arranging these meetings is both time consuming and, at times, frustrating. Bob has brought his task to a successful conclusion with high intellectual standards and with considerable good humor. We thank him for his efforts.

ASMS also offers a series of smaller meetings. The Asilomar Conference is now in its eighth year, largely due to the leadership of Laszlo Tokes. The topic in 1989 was computers in mass spectrometry (chaired by Chris Enke), and the topic of 1990 will be gas phase ion chemistry (chaired by Helmut Schwarz). Our other small research-oriented meeting is on Sanibel Island, Florida; we have had two very successful conferences. In 1989 the topic was desorption ionization mass spectrometry (chaired by Ken Busch, Bob Cotter, and Mark Ross). In 1990, the topic was trapped ion techniques (chaired by Michelle Buchanan and Gary Glish). We continue to offer the fall workshop as an educational event. In 1989, the topic was continuous flow FAB (chaired by Rich Caprioli), and in 1990, the topic will be electrospray mass spectrometry (chaired by Ian Jardine).

We are convinced that our combination of large national meetings and small research or educational meetings is the best way to meet the scientific and intellectual needs of our members. A range of meeting sizes and formats will be even more important in the future as the science of mass spectrometry becomes more and more diverse.

During the last year, the Educational Committee completed work on a brochure titled "What is Mass Spectrometry?" It is intended for our members' use to explain mass spectrometry to fellow scientists, new students, clients, and customers. This brochure has been lovingly produced, and it is a product of which we are very proud. We thank Mike Story and the Education Committee for their hard work on this project.

This year we gave the First Annual ASMS Award for Distinguished Contribution to Mass Spectrometry to Ron Macfarlane. This award is intended to recognize focused achievement in or contribution to funda- mental or applied mass spectrometry. It acknowledges a single unique effort to the field rather than a life-long effort. The award consists of a plaque and $\$ 2,000$.

We also have a continuing series of awards intended to provide research support to young faculty members. There are two such awards: one sponsored by VG Instruments and the other by Finnigan MAT. The award is for $\$ 25,000$ to $\$ 30,000$, which the awardee can use without restriction on direct expenses associated with her or his research. We all recognize how difficult it is for young faculty members in an expensive area like mass spectrometry to get a start. These awards are a big help, and we are most grateful to VG and Finnigan.

I have left, to my way of thinking, the most important to last. ASMS now has its own Journal. Cleverly enough, it is titled The Joumal of the American Society for Mass Spectrometry. Given the healthy financial state of the Society, we were able to provide this Journal to all members with no increase in dues in 1990 . Our arrangement with Elsevier, who publishes the Journal for us, is designed to minimize the cost of the Journal to the members and to libraries. The Board of Directors selected Mike Gross as the furst Editor of this Journal. 'The Associate Editors are Kelsey Cook, Simon Gaskell, Gary Glish, and Sam Houk. We have appointed an Editorial Board that is international in scope. The Editorial process is working smoothly and publication is underway. We are very proud of this Journal, and we are convinced that it will become the premier journal for the publication of research in mass spectrometry. We anticipate that the Journal will increasingly attract the very best research in mass spectrometry.

As my term of office as President comes to an end, I would personally like to thank Judith Watson, our Executive Director, for her help and friendship. Judith is truly devoted to the Society. Without her, the Board of Directors would be unable to do its job. It turns out that this is Judith's 10th anniversary with the Society, and thus, it is appropriate to thank Judith even more warmly than we normally do.

\section{ASMS 1991 CALENDAR}

January 11

Deadline for the submission of abstracts, 39th ASMS Conference on Mass Spectrometry

January 29-February 1 Sanibel Conference on Ion Activation and Dissociation

April 26

May 18-19

May 19-24 Deadline for advance conference registration ASMS Short Courses, Nashville, Tennessee 39th ASMS Conference on Mass Spectrometry and Allied Topics 